Artemy M. Kalinovsky*

\title{
Tractors, Power Lines, and the Welfare State: The Contradictions of Soviet Development in Post-World War II Tajikistan
}

DOI 10.1515/asia-2015-1008

Abstract: This article considers the Soviet campaign to transform the Tajik countryside by mechanizing agricultural production and bringing the welfare state to the villages in light of broader 20th century rural development efforts. It begins by examining the attempt to mechanize agriculture and electrify the Tajik countryside through the eyes of the officials charged with implementing these technologies. Problems with how these technologies were introduced meant that while cotton output expanded, it required increasing amount of labor. Turning to the problem of resettlement, the article emphasizes that resettlement was shaped by competition for labor between districts and farm managers. Increasingly, in the Brezhnev era, it also came to be seen as an easier way to fulfill the modernizing imperative and the commitments of the welfare state. Under pressure to ensure access to schools and medical services, officials found it more convenient to move villages from mountain areas to valleys where such services could be more easily provided. At the same time, the demand for agricultural labor stimulated a kind of "involution" in the countryside, where managers had to find ways to keep labor on the farm. To do so, they could offer cash rewards, building materials, and access to private land and fertilizer.

Keywords: modernization, resettlement, electrification, development, welfarestate

Like many modernizing twentieth century states, the Soviet Union had an ambitious program to transform peasant life, combining economic goals (increased agricultural production) with social ones (enlightenment, the introduction of a welfare state). Though they rarely achieved the ideals of party visionaries or promises touted in propaganda, and indeed brought immense misery to the Soviet peasantry, the collective farms (kolkhozy) set up in the

*Corresponding author: Artemy M. Kalinovsky, University of Amsterdam - European Studies, Spuistraat 134, Amsterdam 1012VB, Netherlands. E-mail: A.M.Kalinovsky@uva.nl 
late 1920s were supposed to fulfill both missions. ${ }^{1}$ From the Khrushchev era onwards, however, the Soviet Union did try to fulfill those earlier promises, investing ever more resources to bring the welfare state to the countryside. Simultaneously, and like many other industrialized countries, the Soviet Union saw a mass exodus of people from the countryside to the cities, as mechanization freed up labor and people sought the opportunities afforded by education and urban living. ${ }^{2}$

The exceptions to this pattern were Central Asia and part of the Caucasus. Although the Soviets never used terms like "modernization" or "development" in the same way as western social scientists, there was nevertheless a set of goals for how the region was to be transformed, some of which stemmed from Marxist-Leninist ideology but others that followed from changing Soviet ideas about the welfare state, the role of women, the Soviet engagement with the Third World, the place of education in the economy and in shaping individual consciousness, and so on. These ideas were formulated and debated by scholars, ideologists, and planners in Moscow, but increasingly in the post-war period, also in the republics themselves. All agreed, however, that progress involved the fading away of religious belief, the movement of agricultural workers into the industrial sector (and the formation of a proletariat consciousness among these workers), the emancipation of women and their participation in the economic and social life of the country, and raising standards of living to even out differences between town and countryside and within the USSR as a whole.

From at least the 1960s, various scholars both within the former Soviet Union and outside of it have grappled with the Soviet Union's seeming failure to modernize the Central Asian countryside. ${ }^{3}$ Specifically, few Central Asians were moving from rural areas into urban ones and from the agricultural sector into the industrial workforce. Few women were engaging in non-household labor or taking advantage of educational opportunities. The failure of Central Asians to leave the rural sector defied the predictions of economists within the Soviet Union and observers outside of it. Development economists had generally assumed that as agriculture became mechanized, "excess" labor would leave the countryside and seek work in cities, providing industrialists with labor. ${ }^{4}$ Most Western scholars

1 As Lynne Viola points out, planner's utopian visions even guided the thinking beyond the punitive "special settlements" for kulaks set up during the collectivization drive of the late 1920s and 1930s. See Viola 2003: 101-128.

2 Siegelbaum/Moch 2014: 124-140.

3 For useful surveys of some of this literature, see Kandiyoti 1996, 2007.

4 I explore these issues in a separate paper, but see also Lewis 1954 and Ranis 2004. 
trying to understand the lack of rural outmigration in Central Asia focused either on political explanations (mechanization was limited because political leaders feared the instability caused by masses of migrants) ${ }^{5}$ or cultural ones, such as the importance of family networks, religious belief, and attitudes about gender. ${ }^{6}$ In this reading, the Soviet state undertook a project of massive social engineering that included mass resettlement, collectivization, and the intervention of the state into family life, and people turned to tradition to shield themselves from these disruptive forces.

As I will argue, Soviet officials remained committed to mechanization and believed that it would ultimately free up labor in the countryside. Drawing primarily on archives from relevant agencies in Soviet Tajikistan, I trace the fate of technologies that Soviet officials believed would allow them to expand cotton production while simultaneously transforming the lives of Central Asian peasants, drawing them into industry and making life for those who stayed on the farm more "modern".

Echoing Jenny Leigh Smith's analysis of Soviet agriculture from the 1930s to the 1960s, I see Soviet industrial farming, for all of its flaws, as relatively successful. ${ }^{8}$ However, I am less interested in Soviet agriculture's success (or lack thereof) at meeting production targets than in the connection between industrialized agriculture and the extension of the Soviet welfare state into the Tajik countryside. My point is not to deny the importance of cultural factors in establishing patterns of work and migration, or the important role of kolkhoz hierarchies, sub-state networks, or the informal or "grey" market for agricultural goods in shaping these processes. Rather, this paper considers the way that the

5 Gleason 1990. Abashin similarly believes that, unable to keep up with the investment necessary to mechanize cotton agriculture, the Soviet state preferred policies that encouraged people to stay on the land. See Abashin 2015: 315-316.

6 There were numerous western analyses of this issue during the Cold War, among the best of which is Lubin 1984.

7 This research is based primarily on materials from the Central State Archive of the Republic of Tajikistan (hereafter TsGART), with some files from the Archives of the Communist Party of Tajikistan (hereafter ACPT) and the Russian State Archive of Contemporary History (RGANI). For the most part, these files reflect the official view - that is, they allow us to trace the way officials thought about certain problems, how they assessed ongoing programs, and the kind of interventions the prescribed. Naturally such sources do not always gives us an accurate picture of what was happening on the farm or even within the ministries or agencies, but they do reveal evolving state logics as well as certain patterns and dynamics. From the Central State Archive of the Republic of Tajikistan, the following collections (fondy) were of particular interest: Fond P1739, the Ministry of Rural Construction, Fond P-288, the Ministry of Agriculture, the Council of Ministers, Fond 18, and the Committee on Labor Resources, Fond 1566.

8 Smith 2014a. 
introduction of technologies that should have been transformative promoted or reinforced certain tendencies. Further, it outlines the kinds of possibilities for engagement and resistance these interventions (inadvertently) provided.

Instead of providing a detailed study of life on a Central Asian farm, ${ }^{9}$ therefore, I explore the campaigns to mechanize agriculture and electrify the Tajik countryside through the eyes of the officials charged with implementing these technologies. Problems with how these technologies were introduced meant that while cotton output expanded, it required increasing amount of labor. I then turn to the problem of resettlement. I emphasize that rather than resulting solely from planning decisions made in Moscow or Dushanbe, resettlement was shaped by competition for labor between districts and farm managers. Increasingly, in the Brezhnev era, it also came to be seen as an easier way to fulfill the modernizing imperative and the commitments of the welfare state. Under pressure to ensure access to schools and medical services, officials found it easier to move villages to areas where such services could be more easily provided. At the same time, the demand for agricultural labor stimulated a kind of "involution" in the countryside, where managers had to find ways to keep labor on the farm. ${ }^{10}$ To do so, they could offer cash rewards, building materials, and access to private land and fertilizer. They also relied on kinship networks and figures of respect within the community, in turn helping shield them from persecution for pursuing religious traditions.

Although this article is not meant as a comparative history, it is useful to keep in mind that what took place in the Soviet Union had contemporaneous equivalents elsewhere, within advanced economies like the United States and modernizing states like India, and in the efforts of international organizations and western donors promoting agricultural modernization. The mechanization of cotton in the United States starting in the late 1940s transformed labor and settlement patterns within the country. In decades that followed, the US, sometimes drawing on the experience of the Tennessee Valley Authority,

9 For an outstanding example of this kind of study, see Abashin's historical-anthropological study of Oshoba, cited in footnote 5. A recent collection which addresses some of the questions this article tries to answer, albeit indirectly, is Dudoignon/Noack 2013.

10 The term is Clifford Geertz's, used to describe the way that Indonesian rice farmers made room for an ever growing labor force, thus upsetting the calculations of development economists who expected a surplus agricultural population to fuel industrialization. See Geertz 1970. But it has recently been used by Jenny Leigh Smith to describe the labor pattern in Uzbekistan's cotton growing valleys. Smith, however, believes that Soviet officials had given up on mechanization for a substantial period and instead tried to create an industrialized system dependent on manual labor. As I emphasize, however, low labor mobility in Central Asia was seen as a critical problem, not a desirable situation. Smith 2014b. 
supported irrigation and mechanization schemes throughout the Third World, including Afghanistan, India, and Egypt. All of these schemes were based on the belief that nature and technology could be harnessed to eliminate hunger, raise standards of living, and free labor for industry. Many of these initiatives faced problems similar to those the Soviet Union would encounter in Central Asia. In some cases, development experts would be frustrated by the failure of farmers to adopt technology; in others, they learned too late the environmental degradation caused by large-scale irrigation or rapidly changing farming practices. (Sometimes, as with the "green revolution", the technology was arguably successful but led to enormous social dislocation, exacerbating rather eliminating inequality). ${ }^{11}$ It is useful to keep these broader parallels in mind as we think about what happened in Central Asia.

\section{Envisioning the modern Tajik village: The cotton economy and the transformation of rural life}

The cotton economy was extensively developed in the late nineteenth century, when Central Asia came under Russian rule, and demand for the crop from Russia's textile industry led local planters to develop its production. Cotton gained particular importance for the Soviet economy when it chose to pursue autarky starting in the late 1920s. ${ }^{12}$ In the post-world war II period, Khrushchev supported initiatives to industrialize Central Asia. At the same time, Khrushchev's commitment to raising standards of living and access to consumer goods, especially clothing, made the increase in cotton production ever more important. "People will be wearing short pants," Khrushchev is supposed to have said, "if we don't get cotton." Additionally, cotton was exported to Moscow's East European allies, and some of its Third World friends, such as India. ${ }^{13}$

In the 1930s, Soviet officials had looked to the Vaksh river as a source for the irrigation of thousands of hectares for cotton growth and industrialization of southern Tajikistan, launching a campaign much like the Ferghana Canal built to carry the waters of the Syr Darya. Although the results of Vaskhstroi were

11 See Cullather 2010; Latham 2010; Mitchell 2002; Unger 2011; Ekbladh 2002.

12 Loring 2014; Teichman 2007; An excellent recent history of cotton as a commodity and its role in the shaping of the industrial world as well as colonial and post-colonial relations is Beckert 2014.

13 Hodnett 1974: 65-66. 
disappointing, they nevertheless set the stage for the transformation of southern Tajikistan from an area inhabited by shepherds and agriculturists based in the mountains to cotton farming centered on the valleys. ${ }^{14}$ World War II and the priorities of rebuilding industry in European Russia meant that no new large-scale projects were undertaken until after Stalin's death. In the 1950s, two potentially contradictory visions emerged for the cotton producing republics of Central Asia. Local officials throughout the region championed the expansion of agriculture, especially cotton, even as they fought for the industrialization of their republics. Tajikistan's officials pushed for the creation of the Nurek Dam, which, besides providing the cheap energy necessary to promote the industrialization of Southern Tajikistan, made possible an enormous expansion of agriculture. For the plan's supporters, the dam promised the possibility of irrigating 80 thousand hectares in the Dangara plain, to the south-east of the proposed dam, by the construction of an immense tunnel. A quarter of this land would be suitable for the highly desired thin-fiber cotton. It would allow for crop irrigation over several hundred thousand acres which were already used for agriculture, make possible the regulation of water in several canals, facilitate mechanical irrigation with the cheap electricity the dam would produce, minimize siltation, and eliminate flooding in the lower Vakh and Amudarya. ${ }^{15}$

Industrialization, modern planning techniques, and renewed efforts to create a welfare state for the peasantry throughout the Soviet Union were supposed to transform life on the collective farms. Mechanization would free up people to join the industrial labor force, while access to schooling medical care, electricity, and comfortable housing would raise standards of living. From the late 1950s until his ouster in 1964, Khrushchev took a personal interest in Central Asia's development and was impatient with party leaders who were slow to catch on with the program and had become used to meeting targets primarily through the limitless mobilization of manual labor. ${ }^{16}$ The cotton industry, which was dominant in Tajikistan and Uzbekistan, was so labor intensive that managers resorted to pulling children out of school during harvest season. ${ }^{17}$ At one point in his memoirs, Khrushchev complained about Usman Yusupov, the Uzbek party boss ousted in 1954: "Many remnants from the past remained in Yusupov's personality. As a man of Muslim background, he regarded women as slaves [whose job was to pick cotton] and he refused to

14 Peterson 2011.

15 Tursunov 1972: 79.

16 On the changing politics between Moscow and the Central Asian republics during the Khrushchev era, see Kalinovsky 2013.

17 "On the misuse of students in the harvest..." 
acknowledge the existence of cotton-harvesting machinery."18 Indeed, mechanization was crucial for reconciling the two visions of economic development - the expansion of agriculture on the one hand and industrialization on the other. The June 1959 Central Committee plenum made the mechanization of cotton-picking an official priority, and in the following months the local party organizations tried to follow through on the campaign. ${ }^{19}$ Khrushchev's statement is in a sense typical of Soviet language that referred to the elements of "feudal" behavior that remained in Central Asia; such criticisms were heard most loudly during periods when the center was most ambitious about pursuing reforms, such as the Khrushchev era and perestroika. It also reveals the frustration of Soviet leaders to whom mechanization seemed a simple enough initiative on paper, but who struggled to understand why it failed to go according to plan in practice. Indeed, as we will see, the frustration was not limited to Khrushchev and officials in Moscow, but was also expressed by party leaders within the republic and more junior officials within ministries and agencies assigned to implement mechanization in the countryside.

Khrushchev believed, not without reason, that the quickest way to transform the republics was to change life on the collective farms. He was not the only one to complain that life on the farms was lagging behind other accomplishments of Soviet modernization; Uldzhabaev, the Tajik first secretary, also complained that the way people lived on Kolkhozes seemed to have changed little since the coming of Soviet power. ${ }^{20}$ In his memoirs, Khrushchev wrote that after visiting Uzbekistan, he "proposed that urban type settlements be constructed, with buildings of three and four stories, and all the conveniences: a public water supply, sewage system, gas lines to the houses, radios, a telephone system, paved roads, and sidewalks. Bakeries, restaurants, kindergartens, and child care centers began to go up." Economic transformation was just one component of a broader transformation of collective lives and individual mind-sets to be achieved through education, architecture, and patterns of work and relaxation. ${ }^{21}$

18 Khrushchev 2006: 349.

19 "Regarding the discussion of the results of the June Plenum in Samarkand..." RGANI Fond 5, opis 31, delo 113, pp 17-18.

20 Meeting of the Tajik intelligentsia, 1956, RGANI Fond 5, Opis 35, d. 29, pp 117.

21 One can get a good sense of how this transformation was visualized by looking at the photographs in the monthly journal Sel'skoe Khoziastvo Tadzhikistana, which had a Russian and a Tajik edition. The journal, intended for farm managers and specialists, featured short articles by scholars and news items about particularly successful farms. Often one can find quite frank discussions about problems relating to mechanization, the use of labor, and other issues. Yet each issue had photographs placed throughout that showed new schools, houses of culture, 
Khrushchev claimed satisfaction about what he found on later visits: "People arriving in these state farms found municipal services of the kind that people need in the modern world: schools, hospitals, cultural centers, movie theaters and so forth... My trips to Turkmenia, Tadzhikistan, and Kirgizia also made a strong impression on me, because similar state farms were established there as well." 22 Khrushchev boasted that "the young women of Uzbekistan were now sitting at the wheels of the tractors and cotton-harvesting combines. This was a battle not just for cotton but also for a higher level of culture in the work process, alleviating the burden for women workers in the cotton fields." 23 But making these proposals a reality on a large scale proved difficult. To give one example, a survey conducted in Uzbekistan in 1961 found that only 23 kolkhoz schools had been completed in the previous year, and that out of 237 schools under construction, work had stopped on 65 due to lack of funds or materials. ${ }^{24}$ The farms either lacked resources to fulfill these projects, or tried to shift the costs to republic and union-level agencies and ministries. Such problems were endemic and affected everything from water distribution to electrification, housing, and health care facilities.

Visions of transforming the Central Asian economies were not limited to Khrushchev and a few top leaders. Throughout the 1960s, 1970s, and 1980s, a growing cadre of social scientists within the republics, including, in Tajikistan, Rashid Rakhimov and Ibadullo Narzikulov, wrestled with the problem of how to raise standards of living in their republics. In the 1960s, they tended to argue for industrialization on the basis of a readily available labor force. By the end of the decade, however, the low rate of urbanization among Central Asians led them to look more closely at what was happening within the collective farms themselves. They began to advocate moving industrial production and education close to the agricultural areas where people lived, increasing investment in cultural facilities, and developing the service sector to provide employment for women and increase access to services. Many of their ideas found support among local party elites and decision makers in Moscow. The details of their debates are not

health clinics, and other "cultural" facilities. Considering that this magazine was primarily for internal consumption, one can interpret the placement of these images not just as propaganda of what had been accomplished but admonishment to the farm managers and specialists to aspire towards the same. Note Michael David-Fox's observation that the so-called "Potemkin villages" in Catherine the Great's Russia were not just meant to impress foreigners, but to demonstrate to the peasants themselves that a better life was possible. David-Fox 2011: 141.

22 Khrushchev 2006: 348.

23 Khrushchev 2006: 350.

24 "Regarding the construction of schools...” RGANI Fond 5, Opis 35, delo 205, 100-101. 
important for this paper, but it is important to keep in mind the varied sources of Soviet "development" schemes when we think about how ideas of making the countryside "modern" were developed. ${ }^{25}$ As we will see below, the Soviet Union threw extensive resources at mechanization and electrification, and measures to raise the standard of living in the Tajik countryside throughout the 1960s, 70s, and 80s, hoping to change how people worked and lived. However, various bottlenecks - some related to the way the distribution of technology was organized, others to the priorities of farm mangers - limited the effect of all of these initiatives.

\section{Electrification and mechanization}

In an issue devoted to electrification in Tajikistan that appeared on February 5, 1956, the newspaper Kommunist Tadzhikistana printed a letter from N. Salimova who complained that her new, two-story apartment building still did not have electricity. This caused a number of difficulties, Salimova wrote: "In each family we have schoolchildren, and in [some families] a few [college] students, and they are forced to work by kerosene lamp. Because of the absence of electricity we do not have the opportunity to use radio receivers and listen to programs." 26 Studying by kerosene lamp was probably not that uncommon in other provincial towns of the USSR, but the letter pointed to a crucial contradiction: a modern, Soviet building, where the residents were not able to properly participate in Soviet life. Lack of electricity made the other elements of Soviet modernity, especially urban modernity, difficult to accomplish.

The 1950s saw a renewed push to bring electricity to the masses. Lenin's famous equation that "Communism = Soviet Power + Electrification" was revived and acquired particular importance in Central Asia. Newspapers and pamphlets trumpeted the transformative nature of electricity for economic and social life and the

25 One can trace these debates through publications of regional academy of science journals, such as the Izvestiya Akademii Nauk Tadzhikistana, which sometimes included "roundtable" debates, various monographs and collections published by these scholars, and even in the press. In terms of seeing the effects of these on policymaking, one finds many instances where the ideas of social scientists are discussed and adapted by republic-level leaders and forwarded to the USSR Council of Ministers (State Archive of the Russian Federation, F.9654, The Council for the Study of Productive Forces, or SOPS (RGAE Fond 399), and individual ministries. Of particular interest are also the many conferences of Central Asian planners and economists held from the 1960s onwards where these issues were discussed and debated (for example, RGAE, F. 399, op 1, d. 1799, 1828, 1873.)

26 Kommunist Tadzhikistana, 5 February 1956. 
role of the Soviet state in making its use widespread. A 1984 study examining the impact of electricity on Central Asia found that "electrification is the key node of fundamental social and cultural changes in a society free from all sorts of exploitation and oppression. It plays a great role in solving not only economic, but social problems - the liquidation of manual and difficult physical labor. Electrification of machines and mechanisms have freed millions of people from difficult manual labor, fundamentally changing its character and content, which, in turn, has changed the social-professional structure of society." ${ }^{27}$ This kind of language had an important place in Soviet writing on modernization, and it paralleled a similar enthusiasm for the transformative possibilities of electrification in the advanced economies of the US and Europe and developing countries of the "Third World". In the case of Central Asia, however, it reflected hopes and aspiration as much as actual achievements.

The electrification of Central Asia did not begin in the 1950s, of course, nor was it completely ignored under Stalin. In fact, the first (albeit low-capacity) generators in what would become Soviet Tajikistan were installed before the revolution, and in the 1930s and 1940s the construction of several larger power stations and dams began. The twentieth party congress gave new impetus to the construction of dams, especially in Tajikistan. The $6^{\text {th }}$ five-year plan, the main Tajik party newspaper proclaimed in capital letters on 7 February 1956, would increase the production of electricity in Tajikistan four-fold. ${ }^{28}$

Yet producing electricity sometimes seemed easier than electrifying the countryside. Many neighborhoods and collective farms were still without electricity long after electricity had become available in the area. The reason was often that the grid had not been completed, or that buildings had not been connected to it - in fact, this was behind the complaint of N. Salimova cited earlier. Rural communities were, as expected, the furthest behind. In 1960, only nine of the 31 collective farms that were supposed to be connected to the grid that year had actually been connected; only $53 \%$ of collective farms in the republic were "considered to be" connected to the grid, but of those only $35 \%$ were actually using electricity. ${ }^{29}$ Fligelman complained: "us builders are getting the impression that we are building high voltage lines to decorate collective farms, cotton fields, and the mountain landscape."30

27 Matnyazov 1984: 154.

28 Kommunist Tadzhikistana, 7 February 1956.

29 "Regarding the electrification of agriculture in the Tajik SSR for 1961-1962" 4 May 1961, State Archives of Tajikistan, Fond 1605, op 1, d. 10.

30 Draft of Y. Fligelman's speech to Tajik Supreme Soviet deputies, 6 July 1960, TsGART, Fond 1605, opis 1 , delo 14 . 
What would keep farms from connecting to the grid? Farms were expected to pay for the costs of electrification themselves, which they were unwilling to do. Farms that were considered poorly performing could petition to have the state pay for electrification. There was thus an incentive to hold off on investing in electrification until the cost could be shifted back to the republic-level government and away from the farm. ${ }^{31}$ Further, many of the farms had small hydroelectric dams and generators installed over previous decades. Indeed, almost a third of electrified farms were using their own small power stations as of 1965. These were unreliable and insufficient for full electrification and mechanization, but they may have been sufficient for the basic needs of administration and services. ${ }^{32}$ Many of these, however, were found to be non-functioning, suggesting that the number of farms that were actually electrified may have been lower than figures suggested. ${ }^{33}$ Even in some of the villages surrounding Nurek City, which were supposed to become a showpiece of Soviet modernity in the countryside, electrification (and running water) arrived only in the late 1970s and early 1980 s.

Between 1958 and 1965 electricity use had more than doubled, and it would double again between 1965 and 1972. ${ }^{34}$ The share of collective farms without access to electricity had shrunk from 49 to $16 \%{ }^{35}$ Yet these figures belie the relatively small impact of electrification within the farms themselves. On the one hand, many more households now had access to electricity for personal use - according to 1965 statistic, $64 \%$ of all households, compares to $27 \%$ in 1958 . Still, even within farms that had access to electricity, $29 \%$ of households were not using electricity. ${ }^{36}$ At the end of the 1970s, Tajikistan still had among the lowest rates of electrification in the country. ${ }^{37}$ Moreover, as we will see, the impact of electrification on the actual production process was small even on those farms where electricity was available.

If electrification was supposed to transform labor in the production process and in the home, and thus people's lives and outlooks, its absence, as Salimova noted in her letter, retarded any other kind of progress. On the farms, absence of electricity was one of the factors leading to limited refrigeration and storing and

31 See, for example, the petitions and response from agencies in TsGART F 18 op 13 d 52, 1-24, and suggestions voiced at a party plenum in 1966, 25-27.

32 “Elektrifikatsia sel'skogo khoziaztvo v 1965 godu," 1 June 1966, TsGART F 18 op 13 d 52, 33; Pirogova 1966: 27.

33 Yunusov 1975.

34 Report on the use of hydropower in rural areas, TsGART F 18 op 13 d 52, 3; Yunusov 1975: 120.

35 Report on the use of hydropower in rural areas, TsGART F 18 op 13 d 52, 3.

36 “Elektrifikatsia sel'skogo khoziaztvo v 1965 godu," 1 June 1966, TsGART F 18 op 13 d 52, 33.

37 Yunusov 1975: 119. 
to the damage of fruit, vegetable, and cotton harvests each year. In the home, lack of electrification placed additional burdens on women, who participated in the work of the collective farm and on personal plots, but had no access to household devices to lessen the burden of their chores there. Since entry into the workforce, in formal or informal ways, did not liberate women from their household obligations, they in fact faced a "double burden" - much like their counterparts in other parts of the Soviet Union, but with even less access to consumer technology and social infrastructure to lighten the load.

Soviet planners and politicians from Khrushchev down to local officials in Tajikistan and the other Central Asian republics envisioned the liberation of people from manual labor through mechanization. Already in the immediate post-war years, officials predicted a full mechanization of all stages of the cotton production process: planting, harvesting, cleaning, and drying. The establishment of the Tashkent Agricultural Machinery plant in 1948 was to make this vision possible by providing the region with the necessary tools. ${ }^{38}$ As the decades passed, however, cotton production continued to rely on manual labour - including child labor - during the harvesting process. As the economist Richard Pomfret demonstrated, Soviet industry in the early 1950s was still unable to produce enough machinery to meet the needs of the farms, but by the 1960s production had increased substantially. Thus, it was at the farm level that managers chose either not to acquire technology or not to use the machinery they did have. For managers, Pomfret argued, using labor was simply cheaper than using machinery. ${ }^{39}$

Pomfret's analysis can be supplemented with archival data from the institutions responsible for overseeing mechanization on the collective farms. These materials show the frustration of republic level officials with the failure of mechanization to transform labor on state and collective farms, and they also point to the reasons that managers and brigade leaders might shy away from using the technology available to them. According to a report from 1966, of the 272 collective farms using electricity, $92 \%$ were using it for production purposes. However, the only sphere of production where machinery was being used to ease the production process was sheep-shearing: 214 farms used electric shears. Only 52 farms used electricity to clean seeds, 36 for irrigation, 26 for milking cows. ${ }^{40}$ The figures were roughly comparable for state and collective farms.

38 "On the State of Cotton Production," 21 December 1948, RGANI F 17 op 138 d 11, 87.

39 Pomfret 2002.

40 "Electrification of Agriculture in the Tajik SSR for 1965" 14 June 1966, TsGART F 18 Op 13 d 52, 34. 
In other words, the problem was not lack of electricity but rather how it was used or not used once it reached the farm.

We see this even more clearly when we look at what happened to machinery on the farm. A report from September 1966 noted that of 73 cotton drying machines inspected that summer, only 32, or less than half, could easily be brought into operation. The rest needed fundamental repairs. ${ }^{41}$ Inspectors found torn wires, missing switches, motors that had been removed and stores in sheds, and in some cases parts that could not be accounted for. Mostly, however, the problems seemed relatively easy to address, providing the materials and personnel could be found. Many of the reports noted that ongoing maintenance work had not been carried out. ${ }^{42}$

Other inspections found that the problem was not too little machinery on collective farms, but too much. Indeed, farms were asking state agencies to buy back machinery. In at least one district, tractors were not being used to full capacity, and inspectors recommended buying the tractors back from collective farms and organizing stations to lend them back to farms as needed. ${ }^{43}$ In Shartuz some $80 \%$ of automobile transport was not functioning in part because there was nowhere to buy spare parts in the district. ${ }^{44}$

The retail agencies for agriculture machinery apparently found it difficult to sell their goods to farms. Farm managers were reluctant to use state bank credits to purchase machinery, and as a result the retailers continued to release machinery with the hope that repayment would come later, absorbing the difference in their own balance sheets. Their warehouses accumulated spare parts and machinery that no one seemed to want, even as new models appeared making the older stock obsolete. ${ }^{45}$

Even though the materials cited above give us the view of officials within ministries, they help us understand why managers would have been slow to adopt technology. Machinery is useful as long as it reduces costs and helps free up labor. But machinery, especially complicated machinery, needs skills to maintain it and spare parts to keep it functioning after heavy use. The reports

41 Lulchak (Head of Energy and Electrification at the Council Of Ministers of the Tajik SSR) to Minister of Agriculture A.N. Maksum, 22 September 1966. TsGART F 18, op 13, d 52, 53.

42 TsGART F 18, op 13, d 52, annex, 54-70.

43 "Questions raised by city and district inspection committees," 27 June 1967, TsGART F 18, op 13, d 61, 28.

44 TsGART F 18, op 13, d 61, 31.

45 "Regarding significant problems in the financial and economic activity of district unions of Tadzhikselkhoztekhnia," note from the Tajikistan branch of the USSR State Bank, 21 April 1967, TsGART F 18 op 13 d 6, 84-86. 
of machinery broken down and sitting idle suggests not so much a refusal to adopt technology, but a failure to use it economically. If there were not enough specialists available to maintain the machinery, nor easily accessible spare parts, machines became a burden rather than a help - and if they proved unreliable during any stage of the production process it therefore made more sense to leave them idling and rely on labor instead. ${ }^{46}$ This was especially true since at least as of the mid 1960s, most harvesting machines were unsuited for the long-staple cotton grown in Tajikistan. ${ }^{47}$ In addition, the machines failed to perform consistently on farms with rolling terrain. ${ }^{48}$ Although engineers and agronomists tried to adapt their designs, their efforts fell short of the demanding and varied terrain in Tajikistan..$^{49}$ Moreover, farm managers, under pressure to meet quotas, may have been unwilling to accept the losses of the harvested crop that happen when machinery is used.

Since the demand for cotton grew faster than the ability to mechanize production, the demand for labor grew as well. Besides the regular collective farm laborers and the local school children used for the harvest, 12 thousand "non-agricultural" workers had to be hired in 1965 and 18 thousand in 1967, at a cost of 5.2 and 7 million rubles respectively. ${ }^{50}$ The Ministry of Agriculture continued to agitate for more machinery to be imported to the republic. Officials calculated that planting of cotton could be shortened from 20-25 days to 5 days, and the harvest to under 60 days while eliminating the need for hiring non-agricultural labor and school-age children if the republic would import 3,500 cotton harvesters and 6,500 trailers to help transport the cotton. ${ }^{51}$ Officials recognized, too, that for this machinery to have the desired effect the entire system of distributing and maintaining machinery would have to be

46 This pattern is by no means unique to the Soviet case. See, for example, Timothy Mitchell's discussion of how Egyptian farmer's, after switching to tractors for plowing and carrying sugarcane with US AID subsidies, ultimately switched back to cow and calf drawn plowing, and switching back to camels for carrying sugarcane. Mitchell 2002: 253-254.

47 "O neobkhodimosti tekhnicheskoy osnashchennosti khlopkovodstva respubliki," October 1968, ACPT F 3 op 23 d 183, 39.

48 "Voprosy razvitiya oroshaemogo zemledeliya v Tadzhikskoy SSR" TsGART F 27 op 15 d 1, 125.

49 See A. Maksumov's critique of available technology in Maksumov 1967 and in the document cited in note 46, above. A. Maksumov, a highly respected agronomist, was the son of Nusratullo Maksum, one of the Tajik leaders executed in 1937. A. Maksumov served as Minister of Agriculture from 1965 to 1971 and later as Deputy Chairman of the Council of Ministers of the Tajik SSR.

50 "O neobkhodimosti tekhnicheskoy osnashchennosti khlopkovodstva respubliki," ACPT F 3 op 23 d 183, 40-41.

51 "O neobkhodimosti tekhnicheskoy osnashchennosti khlopkovodstva respubliki," ACPT F 3 op 23 d 183, 42. 
reformed..$^{52}$ Yet without the Machine Tractor Stations, which were eliminated in 1958, the burden of maintenance fell entirely on the farms themselves, and, as with the irrigation system, they either lacked the cadres to do the work or were otherwise unable to maintain them.

It was still up to the farm managers to decide whether to purchase the machinery and use it. As Pomfret shows, the problem was not that machinery did not reach the republics, but that it was not adopted by the Kolkhoz. This situation did not improve significantly in subsequent years. In 1965, only $14 \%$ of cotton in Tajikistan was harvested mechanically. This number rose to a high of only 36\% in 1980 before sliding down substantially until 1984 and then rising again after 1985, when Perestroika era exposés in the press drew attention to the problem of manual labor, especially child labor, in the cotton complex. ${ }^{53}$ Tajikistan was last even among the Central Asian republics, presumably because access to spare parts and specialists to help maintain the machinery was greater in the other four. At the same time, the stock of harvesters kept growing indeed, by 1980, Tajikistan had roughly the number of harvesters that officials said would be necessary for eliminating the use of school-age children and hiring of non-agricultural labor to bring in the cotton. ${ }^{54}$

Ministry and party officials had only limited means to get farms to mechanize. Even when officials effectively forced machines on the farms they often sat idle. Officials could resort to assigning quotas, but this too had limited effect - when they insisted that farm managers demonstrate that they were adopting mechanization, they sometimes responded by falsifying reports - passing off cotton harvested and processed manually as having been picked and processed by machines. ${ }^{55}$

\section{Resettlement, labor, and the welfare state}

Clearly, with expansion of cotton planting and mechanization taking place so slowly, the resettlement from agriculturally inefficient highlands to newly irrigated lowlands was one of the ways to bring labor where it was needed. However, by the early 1960s, social scientists and planners were already talking

52 "O neobkhodimosti tekhnicheskoy osnashchennosti khlopkovodstva respubliki," ACPT F 3 op 23 d 183, 43.

53 Pomfret 2002: 186.

54 Pomfret 2002: 184. Craumer 1992: 161.

55 “O sostoianiy sokhrannosti sotsialisticheskoy sobstvennosti v kolkhozakh” 1978 TsGART F 288 op 14 d 5279, 67. 
about "surplus" population in the Tajik countryside - yet the resettlements continued. Beyond labor demand, then, two other factors motivated resettlement and shaped the way it was carried out. First, resettlement to accessible valleys offered the possibility of transforming not just where people lived but how - the kinds of houses they occupied, the kind of schooling they received, what they did in their spare time - more easily than in remote mountain villages. Second, as the commitments of the Soviet welfare state grew throughout the 1960s and 1970s, the costs of delivering these goods to mountain villages grew as well, as did concern for those villages located in seismic or otherwise vulnerable areas. Resettlement was thus not just a way to solve a labor supply problem, but also (perhaps more importantly) a way to bring people into modernity and operate the welfare state most efficiently.

Resettlement began on a substantial scale in the 1920s. Between 1925 and 1939, some 400,000 people were resettled from Gharm, Panjikent, and Ura-Tyube, as well as the Ferghana Valley, in the Vakhsh Valley and in the Surkhan-Darya. After the war, the emphasis shifted from resettling individual families and brigades to moving entire farms; further, rather than targeting all densely populated districts, populations were now supposed to come primarily from the mountain areas. ${ }^{56}$ These transfers are usually portrayed as resulting from a central decision or directive. However, an examination of the evidence suggests a more complicated dynamic, where local officials and managers petitioned and lobbied for labor.

Labor hoarding was a feature of the socialist economy. ${ }^{57}$ In the case of cotton agriculture, farm managers, as we saw, preferred to rely on manual labor than bother with machines; this, in turn, led them to lobby for resettlements to their farms. As more and more land was opened up in the 1960s therefore, the need for manpower increased with it. Officials from the committee on labor would visit farms to enquire where labor was needed, where there might be too many hands, and who had the facilities to accept migrants. During these visits, managers of cotton growing farms, especially those with newly irrigated lands, would ask for settlers and promise to find housing and

56 Ferrando 2011: 40-41. On the early Soviet period, see also Kassymbekova 2011, which emphasizes the extent to which settlement was used by officials to secure the southern part of the republic that bordered Tajikistan. The most detailed work on internal migrations produced within Tajikistan is Abdulhaev 2012. Abdulhaev is often critical of how resettlements were executed, but believes they led to economic progress and allowed Tajiks to populate land previously dominated by Uzbeks. 57 See, for example, Filtzer 1994. 
land for them. ${ }^{58}$ Occasionally, farm managers might appeal directly to the Council of Ministers to help speed up resettlement. As one manager of a state farm in the Vakhsh Valley complained in 1967, he had 400 new hectares of irrigated land, but if he did not get 100 families promised to him the farm would not be able to make use of it. ${ }^{59}$ The following year, the head of the resettlement committee explained that all the new land being opened up made an enormous expansion of cotton farming possible, however "the availability of labor resources is not sufficient for solving the problem of irrigating and development of unutilized lands. The only way to provide these farms [with sufficient labor] is to resettle the population of the mountains and foothills areas, as well as the densely populated cities and districts of the Hissar district and the northern group of districts."60

If lowland farm managers wanted the state to send them manpower through resettlement to help with the cotton crop, managers of the highland farms often resisted letting go of labor. Besides arguing with officials and trying to change resettlement targets, they resisted resettlement complaints by simply not doing their part, which was to agitate among farmers and encourage them to leave. ${ }^{61}$ It is impossible to speak with any certainty about their reasons - perhaps they were championing families who had no desire to move, and who may have formed part of an extended kinship network - but the reasons they gave to visiting officials and inspectors was that they needed the labor force themselves. ${ }^{62}$

In theory, resettled families were supposed to find land plots and houses waiting for them, or at the very least have temporary housing and materials for the construction of permanent dwellings, credit for buying livestock, and of course access to schools, stores, running water, and electricity. In addition their transportation costs were covered and they were given some start-up funds. As we saw, district party and state authorities received targets and were supposed to agitate among families to find volunteers for resettlement. At meetings with households, they highlighted the importance of farming the

58 This is reflected in the reports of various local officials; see, for example, the report of A. Nadyrov of his August 1961 tour of Pianj, TsGART F 1566 op 1 d 229, 20-21.

59 Sh. Ulfatov, director of "Guliston" sovkhoz, to First Secretary Rasulov and Chairman of the Council of Minister Kakharov, TsGART F 1566 op 3 d 81, 48.

60 Narzibekov to the Council of Ministers, 26 June 1968, TsGART F 1566 op 3 d 83, 55.

61 Regarding the fulfillment of the Council of Ministers of the Tajik SSR resolution of 11 February 1967 "Regarding the resettlement of collective farm households and other populations from the mountainous and (predgornykh) districts to the irrigated lands of the Tajik SSR," 18 October 1967 TsGART F 1566 op 3 d 81, 72-73

62 TsGART F 1566 op 3 d 81; see also similar report from 14 July 1967 TsGART F 1566 op 3 d 81, 34-35. 
newly irrigated land and the benefits they would receive upon arrival. Relocation was supposed to be voluntary. Unlike the Stalin period, it appears that force was not used to get families to move, though it is likely that some intimidation or coercion did take place. The most basic way to encourage reluctant peasants to move was to dissolve the administrative unit, which oversaw the area and thus cut services. Oral histories conducted after the Soviet period showed that shutting down local stores could put peasants in a particularly difficult situation in the late winter, when the previous year's supply ran low. ${ }^{63}$ Once a group of families agreed to move, they nominated representatives who travelled to their new farms to make final arrangements.

In practice, newly arrived families often found only temporary housing, with inadequate or non-existing school and medical facilities and no running water. The problems extended to all districts and farms; inefficiencies in the construction firms and shortages of materials were part of the problem. The settlers themselves complained about indifference on the part of farm managers. These problems were endemic in the late 1950s, as reports from almost every district where households were resettled indicate. ${ }^{64}$ The situation was only marginally better in the late 1960s and early 1970s. As a result, many families left to return to their home villages. Sometimes, they petitioned officials for permission to return, citing failure to adapt to the new climate or the lack of facilities. In other cases they seem to have simply left. There were incidents of families convincing drivers who had been paid to take them to their new kolkhoz to take them elsewhere - presumably because they had heard bad things about the place where they were expected and preferred to try their luck on another farm. ${ }^{65}$ The fact that farm managers apparently accepted such families rather than reporting them and forcing them to move to farms where they were expected again points to the way labor needs encouraged hoarding among managers and also provided peasants with the means to escape state coercion. ${ }^{66}$

Families who chose to return to their place of origin often found they had an ally in local officials and farm managers there. Managers from farms with a large number of resettled families even complained that officials and managers from highland districts were actively campaigning for these families to return. The

63 Ferrando 2011: 42-43.

64 See the reports in TsGART F 1566, op 1, d 229.

65 To the Matcha region plenipotentiary of the Resettlement Department, 28 July 1963, TsGART F 1566 op $1 \mathrm{~d} 260,21$.

66 Officials from the Council of Ministers chided local officials for allowing such things to take place. Note from Mirzaiantz to the chair of the executive committee of Kulyob M. Sarvarova, 24 June 1967 TsGART F1566 op 3 d 81, 39. 
director of a farm in Shartuz (located in the south of the republic, close to the border with Afghanistan, with almost unbearably hot summers) complained that managers from several farms in Jirgital district were "agitating the households of our collective farm, saying that it's supposedly hot in Shaartuz, move to Jirgital, and in this way they lure farmers away... these households are given land plots, have houses built, they reorganize brigades, stores and schools." ${ }^{67}$ The competition for labor thus created opportunities for families that wanted to escape resettlement.

If labor needs were the primary motive for cotton farm managers to lobby for resettlement, state officials had another: namely, bringing people to Soviet modernity. As officials explained, highland villagers often lived in primitive conditions and made few contributions to the national economy; at the same time they had no access to what was understood by Soviet officials as culture:

The resettlement of people who live in small villages far away from each other in mountainous and foothill regions has a political as well as national-economic importance. The population of these villages that is capable of work is engaged in rainfed agriculture and animal husbandry and as a rule spends 70-110 labor-days per year in collective work, and the rest of the time on their own personal plots. Women are mostly engaged in household work.

The majority of small villages consists of 3 to 20 households and are cut off from any foci of culture, there are no middle schools, hospitals, or clubs, as a result of which children are denied the opportunity to advance their education in eight-year and general education schools, there is insufficient medical care, and no films are shown. ${ }^{68}$

It followed that since bringing schooling, medical care, electricity, and cultural institutions to these remote mountain villages was difficult, it made more sense to move the villages to where they could be integrated into an expanding network of educational, cultural, and welfare facilities.

Because farm managers seemed more enthusiastic about acquiring labor than creating ideal conditions for their livelihood, and because state agencies responsible for providing materials and overseeing residential and other kinds of construction always fell behind on their tasks, resettled families often faced conditions as "primitive" as the ones they had left. A report on the Moscow district in 1959 noted that settlers had no schools or medical facilities waiting for

67 Chairman of Lomonosov State Farm Sadridinnov to Kakharov, date unclear but most likely May 1970, TsGART F 1566 op 3 d 96, 36-38.

68 Note from Narzibekov, undated but most likely from April 1968, TsGART F 1566 op 3 d 83, 26. 
them and had not been extended credit for the purchase of livestock. ${ }^{69}$ Similar problems were found in other districts; many settlers did not even find houses waiting for them. ${ }^{70}$ This problem did not go away in later years. A 1966 inspection of a state farm in Parhar district found that settlers mostly lacked running water or water for their personal plots, had no electricity, no access to building materials for their houses, and were living in inadequate temporary housing. A dozen families had already left and many more threatened to do the same, complaining that the farm management seemed to show no interest in their problems. ${ }^{71}$ The failure of farms to provide housing for settlers sometimes led to delays in resettlement campaigns when officials became aware of the problem ahead of time; in other cases, it led settlers to abandon their new villages and return to their homes. These problems do not seem limited to a particular district, but rather reflected a broader pattern across the republic. ${ }^{72}$

There was another way, however, that resettlement actually worked against the modernization program. As many as $20 \%$ of resettled families returned to their points of origin, which in some cases had been substantially "emptied out" not just of other families but also any state or party presence. They could now farm and raise animals as they chose, and live largely free of any state interference. For example, in the early 1960s thousands of families had been settled from Matcha, in the Zarafshan highlands, to a valley that was then renamed "New Matcha." "3 An inspection in 1968 found that one hundred families had returned and joined the roughly 318 other families that had stayed behind and engaged mostly in sheepherding. The result was a network of sparsely settled villages, some consisting of just one household. ${ }^{74}$ Families acquired relatively large flocks of sheep and cattle. Although the lands in the area technically belonged to a collective farm, "the distance of these lands from the new district (360 km over the Shahristan pass and $710 \mathrm{~km}$ through Samarkand) makes it very difficult for farm management or for village Soviets to maintain constant control over land." Thus, locals were using from " 0.3 to 0.6 " hectares

69 Resolution of the Moscow District Workers' Council, 6 March 1957, TsGART F 1566 op 1 d 229, $10-11$.

70 Resolution of the Parhar District Soviet, 9 April 1959, TsGART F 1566 op 1 d 229, 15-17.

71 Jabirov to Muhamedov, 18 January 1967, TsGART F 1566 op 3 d 81, 17-18.

72 Report on the resettlement of collective farm households for 1967, TsGART F 1566 op 3 d 81, 57-59.

73 On Matcha, see also Ferrando 2011, Zevco 2013, and Abdulhaev 2012: 349-351.

$74 \mathrm{M}$. Shirindjanov, deputy head of the organization department for local councils at the Council of Ministers Note to A.K. Kakharov, Chairman of the Council of Ministers of the Tajik SSR, undated but most likely August 1968. TsGART F 1566 op 3 d 83, 77-79. 
as personal plots, at a time when the republic average was closer to 0.122. Most of the returnees were not involved in any collective work. ${ }^{75}$

The refusal of returnees to take part in collective labor was only part of the problem, however. The families lived largely out of reach of the welfare state as well. Inspectors found that the district had one functioning 8 year school and 25 temporary classrooms housing 640 students. All of these were mud-brick houses, lacked floors or finished ceilings, and were in poor conditions. Some $73 \%$ of school age children did not go to school. The few medical facilities lacked equipment, stores were empty, there was not a single functioning club or library, and not a single movie had been shown since the district was dissolved in 1965. Marriages and births went unregistered, and the registry for military service was out of date. ${ }^{76}$

A similar situation developed in other areas where families resettled from mountain districts returned to their places of origin. ${ }^{77}$ Indeed, dealing with returnees was a major concern of the Committee every year, and persisted at least into the mid 1970s. ${ }^{78}$ The problem was sufficiently widespread that officials devised a standard letter, with only the name of a district and the local committee chairman to be filled in, alerting local officials of the problem and urging them to see through the returnees' re-resettlement. ${ }^{79}$ In the late 1960 s, however, some officials seemed to shift their thinking. Perhaps if these people did not want to move, it made more sense to extend the (welfare) state's reach into the mountains. Thus, in the case of the returnees in Matcha, a senior official in the Council of Ministers recommended organizing a local council to "improve cultural and medical services for the population, increase control over the proper use of land and other natural resources... and also to improve the work of schools, stores, medical and cultural-educational facilities." 80 This approach was consistent with what some Tajik economists began urging around this time - rather than resettling people, planners should think about redistributing

75 TsGART F 1566 op 3 d 83, 78. The figure for average plot size comes from Craumer 1992: 169. Abashin notes that in Oshoba, the farm he studied, the farm chairman offered plots of.15 to.2 hectares to farmers who wished to settle in a new kishlak and farm recently irrigated lands. Abashin 2015: 369.

76 TsGART F 1566 op 3 d 83, 78-79.

77 Narzibekov to H. N. Mirzaiants, Deputy Chairman of the Council of Ministers of the Tajik SSR, 20 March 1967, TsGART F 1566 op 3 d 81, 57-59.

78 Abdulhaev 2012: 375-377.

79 The letter noted that the "children of these families are not covered by the educational system (ne okhvachennyy ucheboy), the population does not get sufficient medical care and is not served by cultural - everyday facilities.” TsGART F 1566 op 3 d 81, 57-58.

80 Shirindjanov to Kakharov, TsGART F 1566 op 3 d 83, 79. 
services and developing industries and agriculture which could employ people in these more remote areas. ${ }^{81}$

For the most part, however, officials still preferred to move people to modernity than bring modernity to the people. In the early 1970 s we see for the first time resettlement plans that seem to be motivated entirely by this impulse and have no mention of labor needs. Geographers urged the resettlement of people within the boundaries of the Southern-Tajikistan Territorial Production Complex into more densely packed villages to help stimulate industrialization and improve the population's access to services. ${ }^{82}$ Thus, in 1972 the executive committee (ispolkom) of the Fayzobod District Workers' Council resolved to move families from 10 isolated villages, noting that the residents "do not work anywhere... their children do not study anywhere, and as a result of this in recent years the district plan for education of children (okhvatu detey obrazovaniem) could not be fulfilled. Because of the villages' remoteness no cultural-education events take place."83 Although the resolution mentions labor and advises that these families be resettled to cotton-sowing areas, the document's phrasing suggests that officials turned to resettlement out of frustration with the difficulty of bringing Soviet modernity to such remote villages. (They were so remote, in fact, that resettlement had to take place by helicopter, as there were no roads in the area.) $)^{84}$

Finally in the 1970s Tajik officials also undertook resettlement of people from geologically unstable areas. The files of the USSR Council of Ministers in Moscow are filled with requests from Dushanbe to help respond to natural disasters usually landslides, floods, or minor earthquakes. Such requests seem to have come on almost yearly basis; unlike other requests for economic subsidies or investment, these were granted without much debate or discussion. By the 1970s, it seems, officials had come to the conclusion that it was better to proactively move people from unstable areas rather than wait for a natural disaster and then undertake recovery operations. Among the groups moved in this period were the Yaghnobi people in North-West Tajikistan. Although the primary concern seems to have been the vulnerability of the Yaghnob villages, their labor was still in demand - collective farms in the lowlands lobbied to receive the new villagers. ${ }^{85}$

81 See, for example: Narzikulov/Kleandarov 1972.

82 See Sattarov 1979.

83 Resolution of the Fayzabod District Council, 12 September 1972, TsGART F 1566 op 3 d 96, 45.

84 TsGART F 1566 op 3 d 96.

85 T. Mirzoaliev, Chairman of the Asht Executive Committee, to Kakharov, 26 March 1970, TsGART F 1566 op 3 d 96, 91-92. 
Nevertheless, their resettlement faced all the same problems as the ones of the 1950s and 1960s - the conditions at their destination were poor, their houses were unfinished, they had no access to cooking fuel, no space to keep their animals, and so on. ${ }^{86}$ In the perestroika period, the resettlement of the Yaghnobis galvanized some Tajikistani intellectuals to campaign for the group to be allowed to return to their place of origin. In fact, the resettlement of the Yaghnobis was among the last of a series of resettlements that stretched back to the immediate post-war period. $^{87}$

We have seen how the expansion of cotton farming, combined with a failure to mechanize agricultural labor, led to a competition for labor, which in turn helped stimulate the mass resettlement of peasants from the highlands to the valleys. Yet resettlement did not solve the labor problem. In fact, the use of child labor, students, conscripts, and even industrial workers and professionals to help bring in the harvest continued. Despite hoarding labor, farm managers still needed more hands to bring in the harvest quickly. Even if a significant part of that labor was arguably "excess," as economists insisted, it still made sense, from the managers point of view, to keep it around for the times of the year when it was necessary. As an incentive, they could offer additional land for personal plots, access to irrigation, fertilizer, tools, through formal and informal mechanisms. $^{88}$

Massive irrigation had made it possible to fulfill one of the post-war goals the expansion of cotton - but the failure to adopt technologies meant that this could be done only by the continued expansion of the labor pool. Up until 1963, Moscow had tried to depress cotton prices to stimulate mechanization, but this only led to stagnation in production. From 1963 onwards prices were raised repeatedly, and the wages of farm workers climbed as well. ${ }^{89}$ As a result, the cost of production rose considerably. ${ }^{90}$ Rising income also encouraged people to stay on the farm, even while officials in Moscow and Dushanbe scratched their heads trying to figure out how to get them out of the village and into the factory. Rising salaries, management willing to reward families with land and access to water and fertilizer, all combined to reinforce a cultural conservatism that encouraged people to stay put.

86 "Regarding the living conditions of resettled households in Zafarabad", 22 October 1970, TsGART F 1566 op 3 d 96, 64-65. See also Abdulhaev 2012: 362-364, 369-373.

87 On the migration of the Yaghnobis, see also Schoeberlein 2000.

88 Poliakov 1992: 28-29.

89 Hodnett 1974: 72-73.

90 “Itogi proizvodstvenno-finansovoy deyatel'nosti kolkhozov" 1978 TsGART F 288 op 14 d 5279, 56. 


\section{Rural construction and the welfare state}

Mechanization, modernization, and the development of (Soviet) cultural institutions may have lagged behind irrigation and the expansion of the cotton crop, but that is not to say that it had ceased to be part of the Soviet project. On the contrary, the 1960s and especially the 1970s saw unprecedented investment in the countryside, while the profits earned by farms also made it possible to invest in facilities. At the March 1965 plenum, about six months after the ouster of Khrushchev, his successors tried to undo many of his reforms but made new commitments to raising the quality of life in the countryside. Among other things, the plenum reduced prices on agricultural goods, cancelled $35-40 \%$ of collective farm debt to the state, increased the funds available for investment in agriculture, and created a pension system for collective farm workers. $^{91}$

In the wake of that plenum, Tajikistan also organized a Ministry of Rural Construction. In some ways, this was a typical Soviet bureaucratic solution, but it is nevertheless significant for several reasons. First, it demonstrated the extent to which the state was making a commitment to improved livelihood in the countryside. Second, it created an authority able to organize not just construction brigades but also the procurement and delivery of materials, always a crucial issue in Tajikistan. The ministry oversaw the expansion of brick factories and units for mixing cement and other materials. It also had a mandate to build facilities to "service the cultural needs of the population", meaning schools, hospitals, clinics, and entertainment venues - all institutions that were expected not just to improve people's lives but to change their consciousness. ${ }^{92}$ It faced some of the same difficulties that plagued the smaller organizations it had replaced or subsumed. Like other agencies, the ministry claimed to lack workers - 2,900 in 1966, among them 150 specialists and 60 engineers. Ministry officials also complained about farm managers being unwilling to settle debts with their construction brigades, or trying to shift construction costs on to other organizations. Nevertheless, it is clear that construction expanded rapidly. The money spent on rural construction nearly tripled from 10 million rubles to 28 million between 1964 and $1967 .{ }^{93}$ In 1967 alone the ministry's brigades had constructed 78 schools,

91 Gordijew 1967.

92 "Regarding the further improvement of services for the cultural needs of the population," 18 March 1979, TsGART F 288 op 13 d 5857, 15. This goal seems to have been even more pronounced in Kyrgyzstan - see Florin 2013.

93 Report of the Tajik SSR Minister for Rural Construction, 1966, TsGART F 1739 op 1 d 1, 5. 
20 pre-school facilities, as well as warehouses, clubs, movie theatres, hospitals and other facilities. ${ }^{94}$ The resources invested in rural construction continued to increase year on year. ${ }^{95}$

The state and the party promised housing, schools, and medical facilities to peasants, and people came to expect them. At a January 1970 meeting of the local council in Ayni, for example, peasants and deputies complained that "many kishloks are in need of residential housing. But they do not have the opportunity to build because construction brigades are never seen in the district."96 As Minister of Rural Construction, who was also a member of the Tajik SSR Supreme Soviet, Jabborov received many such requests and complaints - some from individuals, others from groups of peasants, still others from managers or local officials writing on behalf of individuals, in Russian, Tajik, and Uzbek. The requests varied - one group of peasants asked for a bus to take them from their village to their fields; others complained about the state of the irrigation system on their farm, building materials for their houses, and telephone lines. While some of these are authored by farm managers and thus leave doubt as to whether they reflected the requests of actual peasants, others clearly reflect individual needs and desires. This was most often evident in the case of requests for construction materials. Such requests were also frequently expressed in larger meetings: "Tadzhikpotrebsoiuz [the organization in charge of distributing products to retail chains in Tajikistan] was reproached for failing to provide the retail network with construction materials, and especially saw wood and slate (shifer). At meetings, those who spoke asked for an increase in materials for construction in collective farms... especially of residential houses." 97

Of course these requests cannot be taken as evidence that Soviet modernity was being adopted wholesale. But the aspiration and demand for these "modern" materials should not be overlooked. In my interviews around Nurek, villagers pointed to the availability of materials that came with the dam's construction as one of its most welcome features. Despite the fact that their houses had presumably been adequate, their aspirations were changing. Needless to say it did not mean a wholesale transformation of their way of living. But it is nevertheless a powerful indication. It brings to mind James

94 Report of the Tajik SSR Minister for Rural Construction, 1966, TsGART F 1739 op 1 d 1, 6. 95 Report of the Tajik SSR Minister for Rural Construction, 1972, TsGART F 1739 op 1 d 65, 2. 96 Chairman of the Executive Committee of the Ayni Workers' Council A. Kurbonov to Kakhorov and Minister of Rural Construction Jabborov. TsGART F 1739 op 1 d 5, 9.

97 Report on electoral and reporting meetings on the work of collective farms for 1978, 22 March 1979. TsGART F 288 op 14 d 5857. 
Ferguson's observation, reflecting on his fieldwork in Lesotho, when confronted with the desire of an informant to build a western-style house: "The aspiration to a 'European' home... was not a matter of blind copying, it was a powerful claim to a chance for a transformed condition of life - a place in the world, a standard of living, a 'direction we would like to move in." 98 Like the parents who complained that their children were being sent to pick cotton rather than to school, they were taking the claims of the Soviet modernization project seriously, and calling out officials for failing to deliver.

Life in the countryside was, indeed, being transformed, though perhaps not in the way officials envisioned. People came to expect the state to deliver services and help them build "modern" houses. When the state failed to fulfill its promises (as it inevitably did) they used formal institutions like the Supreme Soviet, meetings with district representatives, and the party to have their demands met, as well as informal networks that operated through those same institutions, much as elsewhere in the USSR. At each level, individuals negotiated their engagement with Soviet modernity and its various avatars - the school, the farm management, the construction brigade, the retail sector, and so on.

\section{Conclusion}

Throughout the 1960s and 1970s, the Soviet Union invested ever more resources to raising the standard of living in the countryside, by building schools and hospitals, raising agricultural wages, and setting up construction agencies to help people improve residential housing. Paradoxically, however, this seems to have actually encouraged people to stay in the countryside. In terms of migration, Soviet Central Asia and part of the Caucasus differed from the pattern within the rest of the USSR and even the US. That this tendency was not explained solely by cultural factors is evident from the enormous flows of migrants that travel to Russia each year - the economy of Tajikistan is dependent on migrant remittances, which were equal to one half of GDP in 2013.

Soviet planners and social scientists, as well as western scholars studying Soviet Central Asia, spent a lot of intellectual energy in the 1960s, 1970s, and 1980s trying to understand the failure of rural outmigration. In the perestroika era in particular, ethnographers, sociologists, and even some economists came to focus on persistent "traditionalism" to explain seeming lack of change in the

98 Ferguson 2006: 19. 
Tajik countryside. ${ }^{99}$ More recently, Kirill Nourzhanov and Christian Bleuer have noted the importance of "informal" economic incentives - including sales from private plots - that kept people on the farm. ${ }^{100}$ Such incentives were real, though they should not be exaggerated - Tajikistan remained the poorest republic in the union, and living standards in the countryside were particularly low. However, these incentives were made possible by the impact of interventions described in this article and the relationship between farm managers and state agencies. ${ }^{101}$ Both the "traditionalism" that some Soviet social scientists believed explained low migration rates and the economic incentives to stay in the countryside were shaped by the Soviet attempts to transform life on the collective farm.

Discussions of Soviet policies in Central Asia sometimes end up becoming a debate over the nature of Soviet actions. What is fascinating about the Soviet case is the dynamic that developed as officials tried to reconcile utopian visions, economic imperatives, and the demands created by local conditions. Cotton demand alone cannot explain the interventions and social upheaval caused in Soviet Tajikistan. Rather, it was (evolving) ideas about what constituted progress in the Central Asian countryside that affected how Soviet planners, agency officials, and farm managers responded to problems of labor, production, and the making of a welfare state for the Tajik countryside. The gap was not between Soviet statements and actual goals - there was no conspiracy to keep the Central Asian population in the countryside - but between the visions espoused in official programs and the technological and organizational capacity to see the necessary interventions through.

Development interventions tend to have unintended consequences. The "green revolution" improved crop yields in some of the countries where it was promoted, but failed to diminish inequality. Moreover, the technologies promoted by agronomists and other experts were adopted selectively, leading

99 Among ethnographers, the debate was started by Iulian Bromley and Ovsey Shkaratan. See Bromley/Shkaratan 1982, which argued that development should focus on national traditions. The idea was supported by some Central Asian economists, who suggested developing cottage industries, but opposed by others, who saw such initiatives as likely to exacerbate problems like child labor. In the perestroika era this kind of thinking became much more prominent. See, for example, Lychigina/Khamkin 1990, and Poliakov 1992.

100 See Nourzhanov/Bleuer 2013: 148-149. Giehler 2013.

101 Abashin, studying these relationships from the perspective of farmers and farm management, similarly underlines that household plots "cannot be considered something completely separate or autonomous from the economy of the collective farm, or even the state economy - they were bound by relationships that were numerous and varied." Abashin 2015: 388. 
to "a hybrid kind of agriculture that did not fulfill the demands of the package approach."102 The Soviet commitment to the welfare state, funded from all-union and republican sources, helped mitigate inequality, but at the same time Soviet interventions often perpetuated the very conditions they were meant to eliminate.

Funding: Nederlandse Organisatie voor Wetenschappelijk Onderzoek 275-52-011.

\section{Bibliography}

Abashin, Sergey (2015): Sovetskiy kishlak mezhdu kolonializmom i modernizatsiey. Moscow: Novoe Literaturnoe Obozrenie.

Abdulhaev, Raqib (2012): Ta'rihi Muhojirat dar Tojikiston (solhoi 1917-2000). Dushanbe: Pazhuhishgohi ta'rih, bostonshinosi va mardumshinosi Akademiqi Fanxoi Jumhurii Tojikiston.

Beckert, Sven (2014): Empire of Cotton: A Global History. New York: Knopf.

Bromley, Yulian/Shkaratan, Ovsey. (1982): "Natsional'nye trudovye traditsii vazhnyy faktor intensifikatsii proizvodstva". Sovetskoe gosudarstvo i pravo 1: 43-54.

Craumer, Peter (1992): "Agricultural Change, Labor Supply, and Rural Outmigration in Soviet Central Asia”. In: Geographic Perspectives on Soviet Central Asia. Edited by Robert A. Lewis. London: Routledge, 132-180.

Cullather, Nick (2010): Hungry World: America's Battle against Poverty in Asia. Cambridge, MA: Harvard University Press.

David-Fox, Michael (2011): Showcasing the Great Experiment: Cultural Diplomacy and Western Visitors to the Soviet Union, 1921-1941. New York: Oxford University Press.

Filtzer, Donald (1994): Soviet Workers and the Collapse of Perestroika: The Soviet Labour Process and Gorbachev's Reforms, 1985-1991. Cambridge: Cambridge University Press.

Dudoignon, Stephane A./Noack, Stephane A. (eds.) (2013): Allah's Kolkhozes: Migration, De-Stalinisation, Privatisation and the New Muslim Congregations in the Soviet Realm (1950s-2000s). Berlin: Klaus Schwarz Verlag.

Ekbladh, David. (2002): “'Mr. TVA': Grass-Roots Development, David Lilienthal, and the Rise and Fall of the Tennessee Valley Authority as a Symbol for U.S. Overseas Development, 1933-1973". Diplomatic History 26.3: 335-374.

Ferguson, James (2006): Global Shadows: Africa in the Neoliberal World Order. Durham, NC: Duke University Press.

Ferrando, Olivier (2011): "Soviet Population Transfers and Interethnic Relations in Tajikistan: Assessing the Concept of Ethnicity". Central Asian Survey 30.1: 39-52.

Florin, Moritz (2013): “Faites tomber les murs! La politique civilisatrice de l'ère Brežnev dans les villages kirghiz". Cahiers du monde Russe 54.1-2: 187-211.

Geertz, Clifford (1970): Agricultural Involution: The Process of Ecological Change in Indonesia. Berkley, CA: UCLA Press.

102 Unger 2011: 136. 
Giehler, Beate (2013): "Maksim Gorki and the Islamic Revolution in the Southern Tajik Cotton Plain: The Failure of Soviet Integration in the Countryside". In: Allah's Kolkhozes:

Migration, De-Stalinisation, Privatisation and the New Muslim Congregations in the Soviet Realm (1950s-2000s). Edited by Stephane A. Dudoignon and Christian Noack. Berlin: Klaus Schwarz Verlag.

Gleason, Gregory (1990): "Marketization and Migration: The Politics of Cotton in Central Asia”. Journal of Soviet Nationalities 1: 66-98.

Gordijew, I. (1967): "Soviet Agriculture and the March, 1965, Plenum of the C.P.S.U". The Australian Quarterly 39. 1: 56-68.

Hodnett, Grey (1974): “Technology and Social Change in Central Asia: The Politics of Cotton Growing”. In: Soviet Politics and Society in the 1970s. Edited by Henry W. Morton and Rudolf Tokes. London: The Free Press.

Kalinovsky, Artemy M. (2013): "Not Some British Colony in Africa: The Politics of Decolonization and Modernization in Soviet Central Asia, 1955-1964”. Ab Imperio 2: 191-222.

Kandiyoti, Deniz (1996): “Modernization Without the Market? The Case of the 'Soviet East”. Economy and Society 25.4: 529-542.

Kandiyoti, Deniz (2007): “The Politics of Gender and the Soviet Paradox: Neither Colonized, Nor Modern?”. Central Asian Survey 26.4: 601-623.

Kassymbekova, Botakoz (2011): "Humans as Territory: Forced Resettlement and the Making of Soviet Tajikistan, 1920-38”. Central Asian Survey 30.3-4: 349-370.

Khrushchev, Nikita (2006): Memoirs of Nikita Khrushchev: Volume 2: Reforme 4, 1945-1964. University Park, PA: Penn State University Press.

Lewis, Arthur (1954): “Economic Development with Unlimited Supplies of Labour”. Manchester School of Economic and Social Studies 22: 139-191.

Loring, Benjamin. (2014): “'Colonizers with Party Cards': Soviet Internal Colonialism in Central Asia, 1917-39”. Kritika 15.1: 77-102.

Lubin, Nancy (1984): Labour and Nationality in Soviet Central Asia: An Uneasy Compromise. London: Macmillan.

Latham, Michael (2010): The Right Kind of Revolution: Modernization, Development, and U.S. Foreign Policy from the Cold War to the Present. Ithaca, NY: Cornell University Press.

Lychigina, N.I./Khamkin, A.S. (1990): "Vliyanie kul'turnykh traditsiy vostoka na khozyaystvennuyu deyatelnost”. Sotsiologicheskie Issledovaniya 4: 13-17.

Maksumov, A. (1967): "Sostoyanie i perspektivy uvelicheniya proizvodstva khlopka sovetskikh tonkovolonistykh sortov v Tadzhikistane”. Sel'skoe Hoziastvo Tadzhikistana 3: 7-16.

Matnyazov, M. (1984): Elektrifikatsiya i ee sotsial'nye posledstviya. Tashkent: Uzbekistan.

Mitchell, Timothy (2002): Rule of Experts: Egypt, Techno-Politics, Modernity. Berkley, CA: University of California Press.

Narzikulov, I.K./Kleandarov, I.M. (1972): “O perspektivakh razvitiya sel'skogo khozyaystva gornykh rayonov Tadzhikistana”. Izvestiya Akademii Nauk Tadzhikskoy SSR 4: 27-32.

Nourzhanov, Kirill/Bleuer, Christian. (2013): Tajikistan: A Political and Social History. Canberra: Australian National University Press.

Peterson, Maya Karin. (2011): Technologies of Rule: Water, Power, and the Modernization of Central Asia, 1867-1941. PhD Dissertation, Harvard University.

Pirogova, Z.A. (1966): Elektroenergetika Tadzhikistana. Dushanbe: Irfon.

Poliakov, Sergey (1992): Everyday Islam: Religion and Tradition in Rural Central Asia. Armonk: M.E. Sharpe. 
Pomfret, Richard. (2002): "State-Directed Diffusion of Technology: The Mechanization of Cotton Harvesting in Soviet Central Asia”. Journal of Economic History 62.1: 170-188.

Ranis, Gustav (2004): “Arthur Lewis' Contribution to Development Thinking and Policy”. Discussion Paper No. 81, Economic Grow Center, Yale University. http://www.econ.yale. edu/growth_pdf/cdp891.pdf (01/13/2015).

Sattarov, A. (1979): "Raselenie sel'skogo naseleniya v yuzhno-Tadzhikskom territorial'no proizvodstvennom komplekse”. Izvestiya Akademii Nauk Tadzhikskoy SSR 3: 47-53.

Schoeberlein, John (2000): "Shifting Ground: How the Soviet Regime Used Resettlement to Transform Central Asian Society and the Consequences of this Policy Today". JCAS Symposium Series 9: 41-64.

Siegelbaum, Lewis/Moch, Leslie Paige (2014): Broad is my Native Land: Repertoires and Regimes of Migration in Russia's Twentieth Century. Ithaca, NY: Cornell University Press.

Smith, Jenny Leigh (2014a): Works in Progress: Plans and Realities on Soviet Farms, 1930-1963. New Haven, CT: Yale University Press.

Smith, Jenny Leigh. (2014b): “Agricultural Involution in the Postwar Soviet Union”. International Labor and Working-Class History 85: 59-74.

Teichman, Christian (2007): "Canals, Cotton, and the Limits of De-Colonization in Soviet Uzbekistan, 1924-1941”. Central Asian Survey 26.4: 499-519.

Tursunov, A. (1972): Torzhestvo Leninskoy idei elektrifikatsii v respublikakh sredney Azii. Dushanbe: Irfon.

Yunusov, B.V. (1975): Eletroenergetika Tadzhikistana. Dushanbe: Irfon.

Unger, Corinna (2011): “Toward Global Equilibrium: American Foundations and Indian Modernization, 1950s to 1970s". Journal of Global History 6.1: 121-142.

Zevco, Ariane (2013): "From Old to New Macha: Mass Resettlement and the Redefinition of Islamic Practice between Tajikistan's Upper Valleys and Cotton Lowlands". In: Allah's Kolkhozes: Migration, De-Stalinisation, Privatisation and the New Muslim Congregations in the Soviet Realm (1950s-2000s). Edited by Stephane A. Dudoignon and Christian Noack. Berlin: Klaus Schwarz Verlag, 148-201.

Note: The research for this article was completed as part of a project on development and modernization in Soviet Tajikistan being sponsored by the Dutch Organization for Scientific Research (NWO). 